\title{
Validation of aflatoxin B1 MIP membrane-based smartphone sensor system for real sample applications
}

\author{
D. V. Yarynka ${ }^{1}$, T. A. Sergeyeva ${ }^{1}$, E. V. Piletska ${ }^{2}$, R. P. Linnik ${ }^{3}$, M. Z. Antonyuk ${ }^{4}$, \\ O. O. Brovko ${ }^{5}$, S. A. Piletsky², A. V. El'skaya ${ }^{1}$ \\ ${ }^{1}$ Institute of Molecular Biology and Genetics, NAS of Ukraine \\ 150, Akademika Zabolotnoho Str., Kyiv, Ukraine, 03143 \\ ${ }^{2}$ University of Leicester \\ University Road, Leicester LE1 7RH, UK \\ ${ }^{3}$ Taras Shevchenko National University of Kyiv \\ 64, Volodymyrska Str., Kyiv, Ukraine, 01601 \\ ${ }^{4}$ National University of "Kyiv-Mohyla Academy" \\ 2, Skovorody Str., Kyiv, Ukraine, 04655 \\ ${ }^{5}$ Institute of Macromolecular Chemistry, NAS of Ukraine \\ 48, Kharkivske Shosse, Kyiv, Ukraine, 02160 \\ d.v.yarinka@imbg.org.ua
}

\begin{abstract}
Aim. To calibrate and validate of innovative MIP membrane-based smartphone sensor system for aflatoxin B1 detection in real cereal samples. Methods. Porous molecularly imprinted polymer (MIP) membranes were synthesized according to the technique of molecular imprinting using the method of in situ polymerization. As a dummy template, ethyl-2-oxocyclopentanecarboxylate was used. Acrylamide was used as a functional monomer according to the results of molecular dynamics. Porous $60 \mu \mathrm{m}$-thick MIP membranes were obtained using UV polymerization for $30 \mathrm{~min}$ (Sergeyeva et al. 2017). The Fluorescent sensor responses of AFB1 binding to the selective MIP membrane surface were recorded by the spectrofluorimeter as well as smartphone camera and further analyzed by smartphone application Spotxel ${ }^{\circledR}$ Reader (Sicasys Software GmbH, Germany). Results. The calibration plots for both MIP membrane-based fluorescent sensor system and smartphone sensor system were obtained. The possibility of successful application of the proposed sensor systems to analyze AFB1 in real samples was demonstrated. Conclusions. The MIP membrane-based smartphone sensor was calibrated and validated for reliable and robust aflatoxin B1 detection in the real cereal samples. The proposed MIP membranebased smartphone sensor system provides affordable, sensitive, and equipment-free technique for AFB1 analysis compared to the traditional analytical methods.
\end{abstract}

Keyword s: aflatoxin B1, molecularly imprinted polymer membranes, smartphone-based sensors.

C 2021 D. V. Yarynka et al.; Published by the Institute of Molecular Biology and Genetics, NAS of Ukraine on behalf of Biopolymers and Cell. This is an Open Access article distributed under the terms of the Creative Commons Attribution License (http://creativecommons.org/licenses/by/4.0/), which permits unrestricted reuse, distribution, and reproduction in any medium, provided the original work is properly cited 


\section{Introduction}

Aflatoxin B1 - is a toxic contaminant regularly found in plant foods and animal feeds where its producers, microscopic fungi Aspergilus, are actively growing. The fungal growth as well as mycotoxin production depends on environmental conditions, which can be changed dramatically and become more suitable for toxigenic microscopic fungi. During the last decades, higher temperatures and humidity have increased the risk of fungal growth and mycotoxin production [1]. Scientists are deeply concerned about the expected growth of toxigenic fungi occurrence and the increasing risk of aflatoxin B1 contamination due to climate change. Besides, there are a number of reports about regular aflatoxin B1 poisoning among pets [2]. Annually AFB1 contamination of food products and feeding stuffs results in significant health and economic problems in many countries [3]. As a result, AFB1 contamination is one of the most severe problems threatening stockbreeding, agriculture, and the food industry all over the world. Therefore, control and screening of AFB1 in plant foods and animal feeds are very important to prevent food poisoning, which in the case of aflatoxin can lead to cancer and even death $[4,5]$.

According to the worldwide aflatoxin regulations, allowed maximum levels of aflatoxin B1 are $0.1-20 \mathrm{ppb}$ in food [6]. The traditional analytical methods like chromatography, mass spectrometry, and immunochemical test systems have been the major appliances that international organizations suggested as standard methods for measuring mycotoxins in food products [7]. However, along with such advantages as high specificity and low detection limits, they possess some usage restrictions related to cost and time. The critical limits of these methods include costly instruments, long measurement time, and complicated detection procedures, which require highly equipped laboratory and well-trained laboratory personnel [8].

As a result, dozens of different analytical strategies for the mycotoxins detection, including biosensors, are presented. According to the current recommendations, novel sensors should be ASSURED. This means that sensors should meet these criteria: be affordable, sensitive, specific, user-friendly, rapid and robust, equipment-free, and deliverable to end-users [9]. So, the development of much simpler and easy-touse analytical devices is of great interest today.

The most promising and suitable analytical technique for modern requirements is optical biosensor, where a smartphone can replace a detector of the sensor signal. In the mass of research, a smartphone combined with biosensor system has been successfully used as a detector or quantifier for optical detection of different toxic chemicals [10]. Taking into account that smartphones can easily take a digital image and use different smartphone apps measuring the concentration-dependent characteristics of this image, they can simplify the detection procedure, make it fast and userfriendly. As AFB1 is the molecule that exhibits native fluorescence, it is advisable to develop fluorescent sensors system for their detection by using a smartphone as a detector and a quantifier of the sensor responses.

As sensing elements for a novel AFB1 sensor, we propose using molecularly imprinted 
polymer (MIP) membranes. On the one hand, MIPs are as sensitive and selective as traditional sensing elements for the mycotoxins sensors like antibodies. On the other hand, MIPs have higher stability, and the process of their synthesis is cheap. So the MIPs-based sensor elements are emerging as a potential alternative to replace the sensing elements based on biomolecules. MIPs are sensitive, selective, stable, cheap, and, more importantly, can generate the fluorescence sensor responses after selective binding AFB1.

Previously a biomimetic sensor for aflatoxin B1 was developed by our group [11]. The developed sensor system was based on the recognition properties of the AFB1-specific MIP membranes, which can generate the fluorescent sensor responses. Also, we demonstrated the possibility of detecting AFB1 sensor responses with a smartphone. As previously shown, polymers-biomimics in the form of free-standing MIP membranes can successfully replace natural biomolecules in the biosensor systems. Also, they can be used as a sensing element mimicking bioreceptors. So this work is aimed at validation of the proposed aflatoxin B1 MIP membrane-based smartphone sensor system and confirmation of the possibility of its application for analysis of the real cereal samples. The procedure of validation and standardization of the proposed MIP membrane-based smartphone sensor system was developed and carried out in cooperation with SE Ukrmetrteststandard.

\section{Materials and Methods}

Materials. Aflatoxin B1 (AFB1), aflatoxin G2 (AFG2), ochratoxin A (OchA), acrylamide (AA), poly-ethylene glycol Mr 20,000 (PEG
20,000), and tri(ethylene glycol) dimethacrylate were purchased from Sigma-Aldrich (St. Louis, USA). Ethyl-2-oxocyclopentanecarboxylate was purchased from (Acros, UK). Oligourethaneacrylate (OUA) was synthesized as described [12]. Other reagents were obtained from Sigma-Aldrich (USA) and used without additional purification.

AFB1 sensor system design. As sensing elements for the AFB1 sensor system, we propose to use molecularly imprinted polymers in the form of a free-standing MIP membranes with synthetic receptor sites in their structure. An optical sensor system for the aflatoxin B1 detection is based on mycotoxins' ability to generate the fluorescence sensor responses after UV irradiation. Therefore, AFB1 can be detected on the surface of the MIP membrane visually as well as quantitatively via spectrofluorimeter or even smartphone.

The MIP membranes were synthesized according to a dummy template-based approach with ethyl-2-oxocyclopentanecarboxylate as a template molecule and acrylamide as a functional monomer [11]. The monomer mixture contained ethyl-2-oxocyclopentanecarboxylate ( $5 \mathrm{wt} \%$ of the total weight of the monomers), acrylamide (AA), with a 1:2 $\mathrm{M}$ ratio of the template: functional monomer; dimethylformamide (50 wt $\%$ ) and polyethylene glycol $\mathrm{Mr}$ $20,000(15 \mathrm{wt} \%)$ as porogen, triethyleneglycoldimethacrylate and oligourethaneacrylate Mr $2600(20 \mathrm{wt} \%)$ as the main components of the polymeric network (with TGDMA/OUA $85 / 15$ ratio). 2,2'-dimethoxy-2-phenylacetone $(0,5 \mathrm{wt} \%)$ was used as an initiator of the polymerization. The compositions of the MIP and corresponding blank membranes are presented in Table 1. 
Table 1. Compositions of the MIP and blank membranes

\begin{tabular}{|l|c|c|}
\hline \multicolumn{1}{|c|}{ Monomer/oligomer } & MIP & Blank \\
\hline $\begin{array}{l}\text { Ethyl-2-oxocyclopentanecarbox- } \\
\text { ylate }\end{array}$ & $20 \mathrm{mg}$ & - \\
AA & $18 \mathrm{mg}$ & $18 \mathrm{mg}$ \\
TGDMA/OUA & $382 \mathrm{mg}$ & $382 \mathrm{mg}$ \\
dimethylformamide & $200 \mu \mathrm{l}$ & $200 \mu \mathrm{l}$ \\
poly-ethylene glycol & $60 \mathrm{mg}$ & $60 \mathrm{mg}$ \\
2,2'-dimethoxy-2-phenylacetone & $10 \mu \mathrm{l}$ & $10 \mu \mathrm{l}$ \\
\hline
\end{tabular}

A mixture of monomers (see Table 1) was polymerized between two glass slides. The thickness of the membranes was regulated by $60-\mu \mathrm{m}$ polytetrafluoroethylene spacers that were placed along the perimeter of the glass slides.

The polymerization was conducted for 30 min using UV light $(\lambda=365 \mathrm{~nm}$, intensity 3.4 $\mathrm{Wm}^{-2}$ ). Then the polymerization was followed by an 8-h Soxhlet extraction procedure in ethanol to remove the template and non-polymerized components from the polymeric network. Also, the poly-ethylene glycol was removed by washing the MIP membranes in the distilled water at $80^{\circ} \mathrm{C}$ for another eight hours. Finally, the MIP membranes and corresponding blank membranes were dried at room temperature and used for aflatoxin B1 detection.

Fluorescent detection of AFB1 using the MIP-based sensor system. The aflatoxin B1 detection by synthetic receptor sites in the MIP membrane structure is based on the toxin's ability to fluorescence. For this purpose, $1 \mathrm{~cm} \times 2 \mathrm{~cm}$ membrane samples were incubated in 5-500 ppb solutions of AFB1 (20 mM Na-phosphate buffer ( $\mathrm{pH}$ 6.0) containing $10 \%$ of acetonitrile). After that, the membranes were dried at room temperature and fixed in a hold- er for membranes and polymers. The sensor responses were registered after UV-irradiation directly at the membranes' surface using PerkinElmer LS 55 (UK) spectrofluorimeter (excitation wavelength $365 \mathrm{~nm}$ ). The data were collected in the range of $390-550 \mathrm{~nm}$, and the peaks were in $435 \mathrm{~nm}$.

Smartphone-based sensor system for AFB1 detection. The procedure of fluorescence signal measurement with the MIP membranebased smartphone sensor system is presented in Fig. 1. The quantitative detection of AFB1 using the smartphone is also based on the fluorescence phenomenon and the possibility of its visual detection. It occurs when the sample is excited with UV light, and the mycotoxin's fluorescence from the excited sample passes through a lens to the smartphone camera (Fig.1, a). Then it could be measured either with the smartphone application or detected by the naked eye. As in the previous case, the MIP membrane samples were incubated in an aqueous solution with different concentrations of aflatoxin B1. Then the dried $1 \times 1 \mathrm{~cm}$ MIP membrane samples were placed on a black, matt A4 cardboard and UV-irradiated using TMW-20 transilluminator equipped with UV Wood glass (UVP, Upland, CA, USA) for $1 \mathrm{~min}$. After $1 \mathrm{~min}$ excitation, the digital images were taken with the smartphone camera (Meizu 16 equipped with $20 \mathrm{MP}$ camera, f/1.8) fixed perpendicularly to the surface at the distance of $25 \mathrm{~cm}$ to the membrane samples using a photographic tripod. Then the taken digital images in JPEG format (dimensions $4032 \times 3024$ pixels) were processed with smartphone application Spotxel ${ }^{\circledR}$ Reader (Sicasys Software GmbH, Heidelberg, Germany), see Fig.1, b. Smartphone application represented the relative fluorescent intensity 

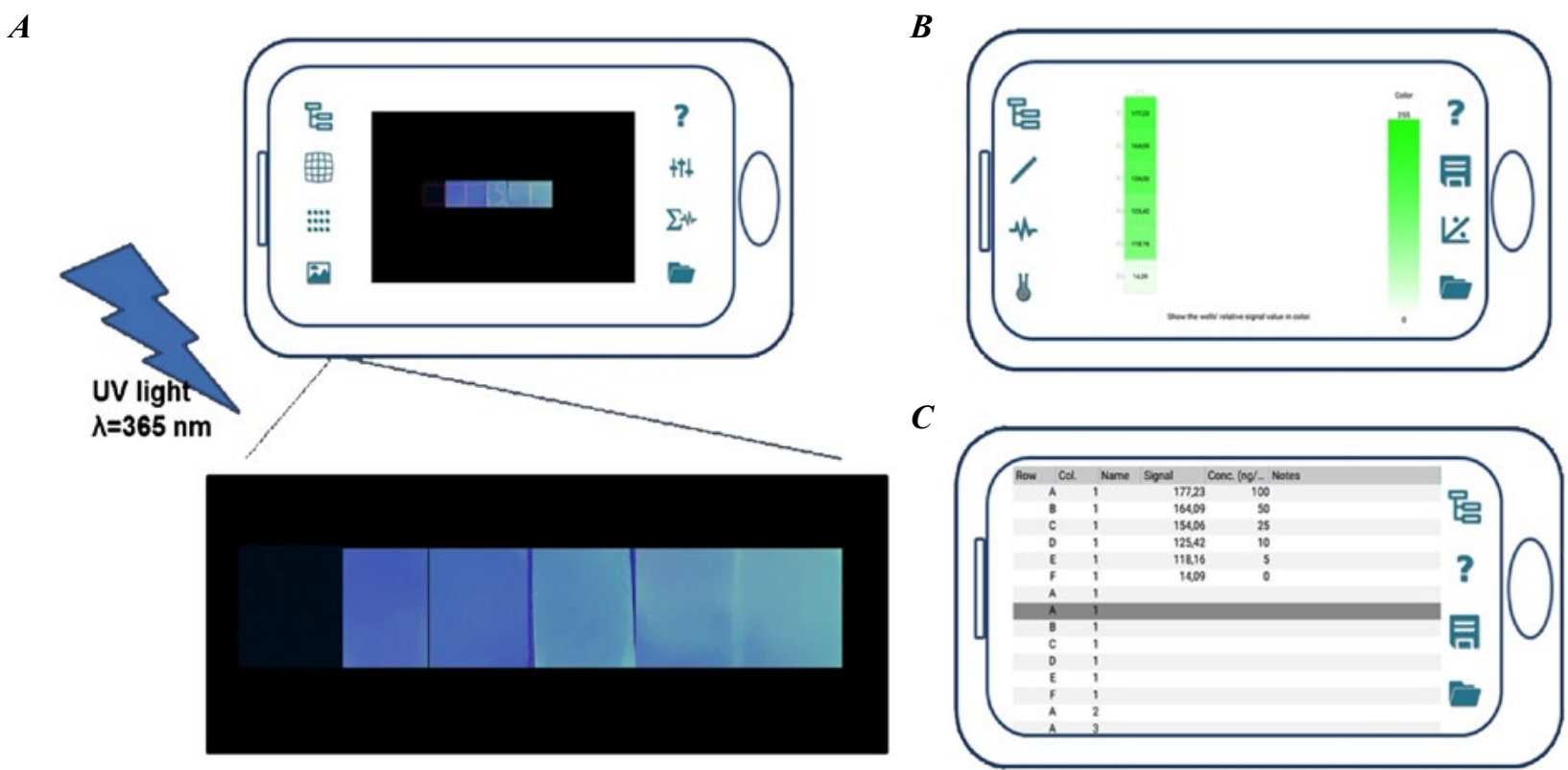

Fig.1. Fluorescence signal measurement procedure of the MIP membrane-based smartphone sensor system using smartphone application Spotxel ${ }^{\circledR}$ Reader: $A$ - scheme of MIP membrane fluorescence signal measurement with smartphone camera; $B$ - fluorescence signal processing by smartphone application Spotxel ${ }^{\circledR}$ Reader; $C$ - exemplary fluorescence data analysis of the smartphone-taken images.

expressed in arbitrary units, which was used as a parameter for AFB1 quantification and for the construction of the standard calibration curve within real-time (Fig.1, c).

AFB1 detection in real samples. To investigate the feasibility of our sensor systems, both fluorescent and smartphone one, AFB1 analysis was performed for real samples. For this purpose, the AFB1-free flour samples (wheat, maize, rye flour) from different manufacturers were purchased in the local supermarket. As previously described AFB1 was extracted from flour samples. The flour sample $(1 \mathrm{~g})$ was mixed with $10 \mathrm{ml}$ of $80: 20 \mathrm{v} / \mathrm{v}$ acetonitrile: $\mathrm{H}_{2} \mathrm{O}$ solution and shaken for 10 min (Vortex laboratory shaker (Fisher Scientific, Germany)). The supernatant was collected using filter paper. The procedure was repeated. All the extracts were collected and centrifuged for $10 \mathrm{~min}$ at 10,000 g. AFB1-free flour extracts were spiked with different concentrations of (20-80 ppb ) AFB1. The supernatant fluid was diluted 1:10 with the buffer (20 mM Na-phosphate buffer ( $\mathrm{pH}$ 6.0) containing $10 \%$ of acetonitrile) and was further analyzed for the AFB1 presence using the fluorescence or smartphone sensor systems. The concentration of AFB1 in the solid flour sample was calculated as described earlier [11].

Statistical analysis. All measurements were made ten times. The obtained results were statistically processed using the computer program Microsoft Excel. Replicates were the experimental units. The data of mean, standard deviation, relative standard deviation were determined. The data were expressed as means. 


\section{Result and Discussion}

Before determining AFB1 in real cereals samples, calibration curves of the proposed sensor systems are required. Since the aflatoxin B1 detection is based on its natural ability to fluorescence, sensor signals were initiated by UV-irradiation $(\lambda=365 \mathrm{~nm})$. First of all, using standard solutions with different AFB1 concentration the calibration curve for the fluorimetric MIP membrane-based sensor system was obtained (Fig. 2).

The limit of detection $(3 \sigma)$ of the proposed sensor system with spectrofluorimeter as analyzer was calculated as $10 \mathrm{ppb}$. The limit of detection of the proposed fluorimetric sensor system corresponds to the generally accepted standards for the determination of aflatoxin B1 in food or other edibles which are approved worldwide. Also, this sensor system in configuration with spectrofluorimeter demonstrated a wide linear dynamic range from 10 to 500 ppb. Moreover, the analytical curves presented good linearity with $\mathrm{R}^{2}$ higher than 0.99 . The MIP-membrane-based sensor system demonstrated high sensor responses after AFB1 addition, while insignificant sensor signals were observed in control experiments, where membranes synthesized in the absence of the dummy template were used as selective elements of the sensor.

In addition, using close structural analogs of aflatoxin B1 (aflatoxin G2 and ochratoxin A) cross-reactivity of the proposed MIP membranes-based sensor system were determined. According to the obtained results (Fig. 3), the MIP membranes can successfully differentiate analyte of interest from its close structural analogs. So the MIP membranes-based sensor system demonstrated significantly higher selectivity towards aflatoxin B1 as compared with others mycotoxins.

In order to simplify the detection procedure and make it suitable for end-users in nonlaboratory conditions, the smartphone was

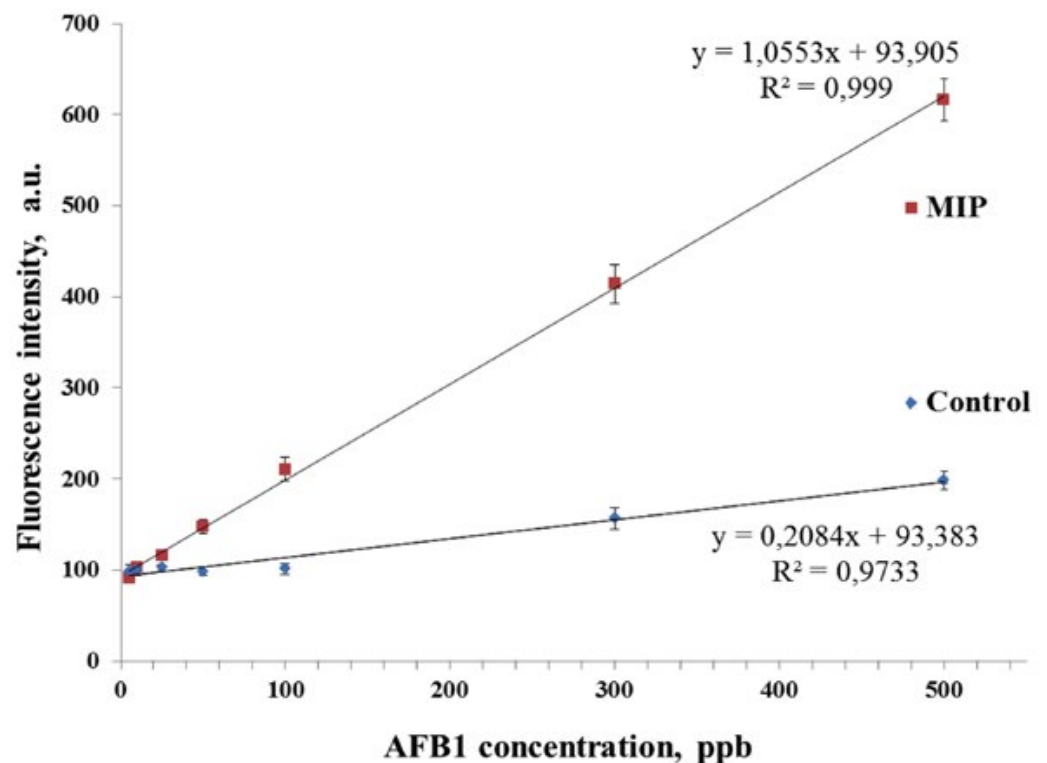

Fig. 2. Calibration plots of the MIPmembrane-based fluorescent sensor system for AFB1 detection. Fluorescence of acrylamide-based MIP and control polymeric membranes after incubation in solutions with different concentrations of AFB1 in $20 \mathrm{mM}$ Na-phosphate buffer ( $\mathrm{pH}$ 6.0) containing $10 \%$ of acetonitrile. Spectrofluorimeter PerkinElmer LS 55 (excitation wavelength $365 \mathrm{~nm}$, emission wavelength of $435 \mathrm{~nm}$ ). Error bar - SE, $n=10$. 
used for the analysis of sensor responses generated on the surface of the MIP membrane. Therefore, the proposed MIP membranes were incubated in solutions with the same concen-

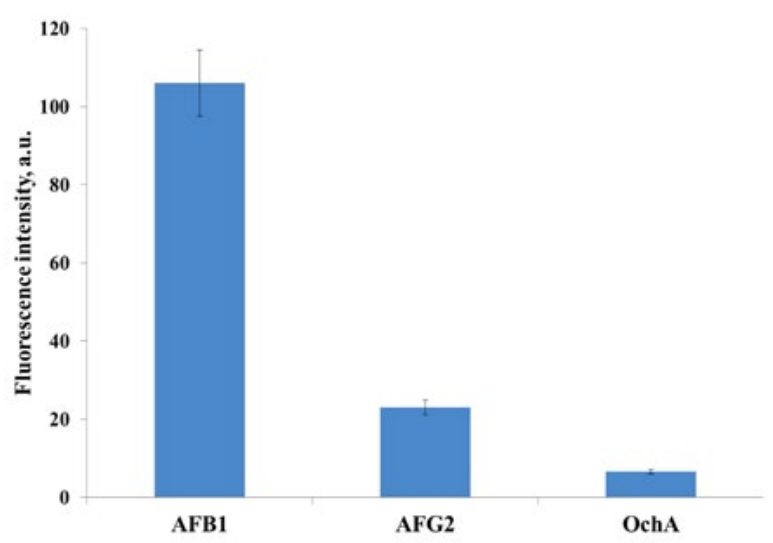

Fig. 3. Cross-reactivity of the fluorescent MIP membrane-based sensor system for aflatoxin B1 detection. Fluorescence of acrylamide-based MIP membranes after incubation in $100 \mathrm{ppb}$ solutions of aflatoxin B1, aflatoxin $\mathrm{G} 2$ and ochratoxin A (20 mM Na-phosphate buffer (pH 6.0) containing $10 \%$ of acetonitrile was used for the measurements). Error bar - SE, $n=5$. trations of aflatoxin B1 as in the previous case. However, the sensor responses were analyzed by a smartphone camera. Hence, a calibration graph of the fluorescence intensity from the toxin concentration in the analyzed sample was obtained (Fig. 4). Then, the obtained calibration graph was used to determine aflatoxin B1 in real samples using a smartphone.

In addition, the limit of detection and the linear dynamic range are required for calibration of the proposed smartphone sensor system. So, as in the previous case, these working parameters of the sensor system based on a MIP membrane and a smartphone for aflatoxin $\mathrm{B} 1$ detection were determined.

The limit of detection for smartphone-based sensor system was estimated as $15 \mathrm{ppb}$. The dynamic range with linear responses from 15 to $300 \mathrm{ppb}$ was demonstrated (see Fig. 4). The obtained limit of detection and the linear dynamic range were slightly less than in the previous case but still meet the standards of sensors for the mycotoxin detection.

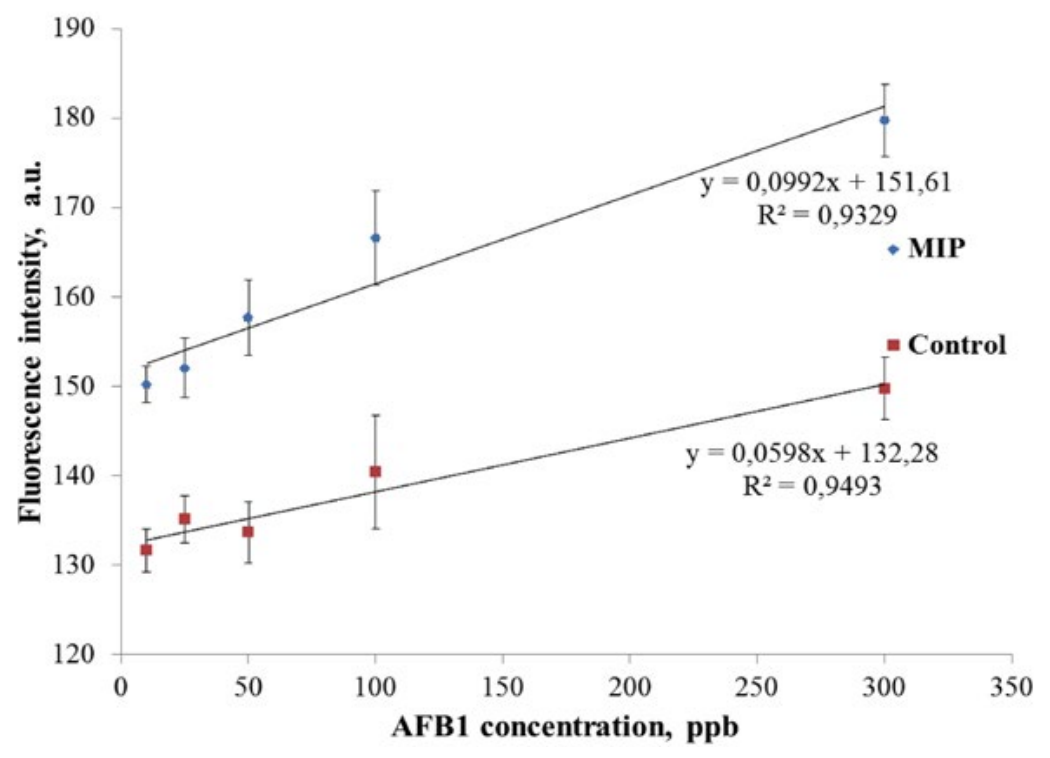

Fig. 4. Calibration curve of the MIPmembrane-based smartphone sensor system response against the concentration of AFB1. Fluorescent sensor responses were estimated by smartphone application Spotxel ${ }^{\circledR}$ Reader (Sicasys Software GmbH, Heidelberg, Germany) after incubation MIP and control membranes in solutions with different concentrations of AFB1 (20 mM Na-phosphate buffer (pH 6.0) containing $10 \%$ of acetonitrile). Error bar - SE, $n=5$. 
Finally, in case of standardization, the proposed MIP membranes-based smartphone sensor system was applied for aflatoxin B1 analysis in real samples. For this purpose, commodity extracts were obtained from flour samples produced by different Ukrainian manufactures. Moreover, to prove the possibility of aflatoxin B1 detection by the proposed sensor system in different matrixes, wheat, maize, and rye flour were chosen.

Firstly, the obtained commodity extracts were analyzed using the MIP membranes and the spectrofluorimeter. The aflatoxin B1 fluorescence spectra obtained from spectrofluorimeter were compared with the typical calibration graphs for this sensor system and the concentration of aflatoxin B1 in samples was determined. The results obtained are presented in Table 2.

It is well known that the repeatability of analytical methods is satisfactory when mean recoveries are $70-120 \%$ and RSDs are $\leq 20 \%$ $[13,14]$. It can be observed that all samples demonstrated good recovery between 93.7 and $104.2 \%$ with satisfactory precision since the RSD values were lower than $18.1 \%$.

Secondly, the sensor system based on MIP membranes as sensitive elements and a smartphone as a detector and analyzer were tested for the aflatoxin B1 analysis in real flour samples. The results of the determination of aflatoxin B1 in different flour samples using the proposed sensor system are presented in Table 3. According to the obtained results, mean recoveries are $105.3 \%$. The RSD values were lower than $15.5 \%$. So the repeatability of this analytical method was clarified as satisfactory as well as the precision of the proposed method.

According to the obtained results, the proposed sensor systems based on highly-sensitive and selective MIP membranes provide a reliable approach for food safety testing with good recovery and satisfactory precision. As compared to most conventional methods, the proposed MIP-based sensors could provide considerably lower time of analysis and cost of mycotoxin testing for the feed and food industries. Moreover, the extraction procedure requires a small volume of samples and is ecologically safe as compared to other traditional analytical methods.

\section{Conclusions}

The aflatoxin B1 sensors systems based on the molecularly imprinted polymer membranes were calibrated. Consequently, the MIP membrane-based fluorimetric sensor system

Table 2. Aflatoxin B1 detection in real flour samples

\begin{tabular}{|l|c|c|c|c|}
\hline \multicolumn{1}{|c|}{ Sample No. } & Added, ppb & Found, ppb & Recovery, \% & RSD, \% \\
\hline wheat flour "KyivMlyn", Kyiv, Ukraine & 20 & $20.3+2.15$ & 101.7 & 18.1 \\
maize flour "Lavka Tradytsiy",Lviv, Ukraine & 90 & $84.3+1.5$ & 93.7 & 3.1 \\
wheat flour "Khutorok", Zmiiv, Ukraine & 60 & $56.7+1.4$ & 94.4 & 4.1 \\
maize flour "Dobrodiya Foods", Kyiv, Ukraine & 40 & $41.7+1.4$ & 104.2 & 5.7 \\
wheat flour “Aro", Kyiv, Ukraine & 80 & $82.7+0.5$ & 103.3 & 1.1 \\
\hline
\end{tabular}

RSD - relative standard deviation 
Table 3. Aflatoxin B1 detection in real flour samples using MIP membrane-based smartphone sensor system

\begin{tabular}{|l|c|c|c|c|}
\hline \multicolumn{1}{|c|}{ Sample } & Added, ppb & Found, ppb & Recovery, \% & RSD, \% \\
\hline maize flour "Lavka Tradytsiy",Lviv, Ukraine & 20 & $26.3+3.7$ & 105.3 & 13.9 \\
maize flour "Dobrodiya Foods", Kyiv, Ukraine & 30 & $32.9+5.1$ & 109.6 & 15.5 \\
wheat flour, "Zernovita", Ozeryanka, Ukraine & 40 & $38.5+1.9$ & 96.3 & 4.9 \\
wheat flour "Aro", Kyiv, Ukraine & 50 & $47.9+6,9$ & 95.9 & 14.6 \\
rye flour “Dobrodiya Foods", Kyiv, Ukraine & 60 & $66.3+6.5$ & 110.6 & 9.8 \\
maize flour “Alta Vista", Kyiv, Ukraine & 80 & $85.3+6.9$ & 106.7 & 8.0 \\
wheat flour "EuroMill”, Boryspil, Ukraine & 90 & $93.5+11.2$ & 103.9 & 12.0 \\
wheat flour "Khutorok", Zmiiv, Ukraine & 150 & $143.9+19.8$ & 96.0 & 13.7 \\
wheat flour "Zernari”, Oleksandriya, Ukraine & 250 & $259.2+21.3$ & 103.7 & 8.2 \\
wheat flour "KyivMlyn", Kyiv, Ukraine & 300 & $316.5+22.1$ & 105.5 & 7.0 \\
\hline
\end{tabular}

RSD — relative standard deviation

achieved a wide linear dynamic range from 10 to $500 \mathrm{ppb}$ with a low LOD of $10 \mathrm{ppb}$. Aflatoxin B1 was detected with high selectivity using the proposed MIP membrane-based sensor system as compared to other mycotoxins. The smartphone sensor system based on the MIP membranes was also characterized with a broad linear dynamic range from 15 to $300 \mathrm{ppb}$ and low LOD of $15 \mathrm{ppb}$. The detection of aflatoxin B1 in real extracts from wheat, rye, and maize flour was successfully validated. As compared to the traditional methods, the MIP membrane-based sensor systems provide affordable, simple, rapid, and robust analytical technique for the aflatoxin B1 analysis. In cooperation with SE Ukrmetrteststandard a complete set of metrological studies for the developed sensor system was conducted, and the proposed method for the aflatoxin B1 detection in flour samples was standardized.

\section{Acknowledgments}

Financial support from the National Academy of Sciences of Ukraine (programe "Smart sens- ing devices of the new generation based on modern materials and technologies").

\section{REFERENCES}

1. Daou R, Joubrane K, Maroun RG, Khabbaz LR, Ismail A, el Khoury A. Mycotoxins: Factors influencing production and control strategies. AIMS Agricult Food. 2021; 6(1): 416-47.

2. Martínez-Martínez L, Valdivia-Flores AG, Guerrero-Barrera AL, Quezada-Tristán T, Rangel-Muñoz EJ, Ortiz-Martínez R. Toxic Effect of Aflatoxins in dogs fed contaminated commercial dry feed: a review. Toxins. 2021; 13(1): 65.

3. Mamo FT, Abate BA, Zheng Y, Nie C, He M, Liu Y. Distribution of Aspergillus fungi and recent aflatoxin reports, health risks, and advances in developments of biological mitigation strategies in China. Toxins. 2021; 13(10): 678.

4. Williams JH, Phillips TD, Jolly PE, Stiles JK, Jolly CM, Aggarwal D. Human aflatoxicosis in developing countries: a review of toxicology, exposure, potential health consequences, and interventions. Am J Clin Nutr. 2004; 80(5): 1106-22.

5. Marchese S, Polo A, Ariano A, Velotto S, Costantini $S$, Severino L. Aflatoxin B1 and M1: Biological properties and their involvement in cancer development. Toxins. 2018; 10(6): 214. 
6. Miklós G, Angeli C, Ambrus Á, Nagy A, Kardos V, Zentai $A$ et al. Detection of Aflatoxins in Different Matrices and Food-Chain Positions. Front Microbiol. 2020; 11:1916.

7. Singh J, Mehta A. Rapid and sensitive detection of mycotoxins by advanced and emerging analytical methods: A review. Food Sci Nutr. 2020; 8(5): 2183-204.

8. Krska R, Schubert-Ullrich P, Molinelli A, Sulyok $M$, MacDonald $S$, Crews $C$. Mycotoxin analysis: An update. Food Addit Contam. 2008; 25(2): 152-63.

9. Hussain I, Bowden AK. Smartphone-based optical spectroscopic platforms for biomedical applications: a review. Biomed Opt Express. 2021; 12(4): 1974-98.

10. Liu J, Geng Z, Fan Z, Liu J. Bioelectronics HC-B and, 2019 undefined. Point-of-care testing based on smartphone: The current state-of-the-art (20172018). Biosens Bioelectron. 2019; 132: 17-37.

11. Sergeyeva T, Yarynka D, Piletska E, Linnik R, Zaporozhets $O$, Brovko $O$ et al. Development of a smartphone-based biomimetic sensor for aflatoxin B1 detection using molecularly imprinted polymer membranes. Talanta. 2019; 201: 204-10.

12. Spirin YuL, Lipatov YuS, Magdinets VV, Sergeyeva LM, Kercha YuYu, Savchenko TT et al. Polymers based on polyoxypropylene glycol, diisocyanate and ethylene glycol monomethacrylate. Polymer Science USSR. 1968; 10(9): 2463-70.

13. Guideline ICHHT. Validation of analytical procedures: text and methodology. Q2 (R1) 2005; 1: 05.

\section{Валідація сенсорної системи на основі МІП мембран і смартфону та її використання для аналізу реальних зразків}

Д. В. Яринка, Т. А. Сергеєва, О. В. Пілецька, Р. П. Линник, М. З. Антонюк, О. О. Бровко, С. А. Пілецький, Г. В. Сльська

Мета. Калібрування та валідація інноваційної сенсорної системи на основі МІП мембран та смартфону для виявлення афлатоксину В1 у реальних зразках зернових. Методи. Пористі молекулярно-імпринтовані полімерні (МІП) мембрани синтезовано in situ згідно методу молекулярного імпринтингу. Етил-2- оксоциклопентанкарбоксилат виконував функції псевдоматриці. Функціональний мономер - акриламід обрано відповідно до результатів молекулярної динаміки. Пористі МІП мембрани товщиною 60 мкм отримували в результаті УФ-полімеризації впродовж 30 хв (Сергеєва та ін. 2017). Флуоресцентні сенсорні відгуки АФВ1, зв'язаного з поверхнею селективних МІП мембран, реєстрували з використанням як спектрофлуориметру, так і камери смартфону з подальшим аналізом за допомогою програми для смартфонів Spotxel® Reader (Sicasys Software GmbH, Німеччина). Результати. Отримано калібрувальні графіки як для флуориметричної сенсорної системи на основі МІП мембран, так і для сенсорної системи на основі смартфона. Показано можливість успішного застосування запропонованих сенсорних систем для аналізу АФВ1 в реальних зразках. Висновки. Сенсор на основі МІП мембран був відкалібрований та валідований для надійного та точного виявлення афлатоксину В1 у реальних зразках зернових. Порівняно з традиційними аналітичними методиками, запропонована сенсорна система на основі смартфону та МІП мембран — це доступна, чутлива технологія для аналізу АФВ1, яка не потребує використання спеціалізованого лабораторного обладнання. Кл юч о в і с л ов а: афлатоксин В1, молекулярно-імпринтовані полімерні мембрани, сенсори на основі смартфонів.

\section{Валидация сенсорной системы на основе МИП мембран и смартфона и ее использование для анализа реальных образцов}

Д. В. Яринка, Т. А. Сергеева, О. В. Пилецкая, Р. П. Линник, М. 3. Антонюк, А. А. Бровко, С. А. Пилецкий, А. В. Ельская

Цель. Калибровка и валидация инновационной сенсорной системы на основе МИП мембран и смартфона для обнаружения афлатоксина В1 в реальных образцах зерновых. Методы. Пористые молекулярно-импринтированные полимерные (МИП) мембраны синтезированы in situ с использованием метода молекулярного импринтинга. В качестве матричной молекулы использовали этил-2-оксоциклопентанкарбоксилат. Акриламид был использован в качестве функционального мономера согласно результатам молекулярной динамики. Пористые МИП-мембраны толщиной 60 мкм получа- 
ли с помощью УФ-полимеризации в течение 30 мин (Сергеева и др., 2017). Флуоресцентные сенсорные сигналы АФВ1, связанного с поверхностью селективных МИП мембран, регистрировали как с помощью спектрофлу-ориметра, так и камеры смартфона с последующим анализом с помощью приложения для смартфона Spotxel® Reader (Sicasys Software GmbH, Германия). Результаты. Получены калибровочные графики как для сенсорной флуориметрической системы на основе МИП мембран, так и для сенсорной системы на основе смартфона. Показана возможность успешного применения предложенных сенсорных систем для анализа АФВ1 в реальных образцах. Выводы. Сенсор на основе МИП мембран был откалиброван и валидирован для надежного и точного обнаружения афлатоксина В1 в реальных образцах зерновых. По сравнению с традиционными аналитическими методиками, предложенная сенсорная система на основе смартфона и МИП мембран - это доступная и чувствительная технология для анализа АФВ1, которая не требует использования специализированного лабораторного оборудования.

К л юч е в ы е сл о в а: афлатоксин В1, молекулярно-импринтированные полимерные мембраны, сенсоры на основе смартфонов.

Received 30.07.2021 